\title{
Muslim Alternative Dispute Resolution: Tracing the Pathways of Islamic Legal Practice Between South Asia and Contemporary Britain
}

\section{JUSTIN JONES}

\begin{abstract}
In recent decades, a wide array of alternative dispute resolution (ADR) forums have taken shape within British Muslim communities. Exploring the development of Muslim ADR practices in contemporary Britain, this paper argues that these quasilegal mechanisms are not entirely novel formations created afresh in the modern British socio-legal context; but rather, they have antecedents in long-standing cultural and religious norms that can be traced back to colonial-era South Asia. In the Indian subcontinent under British rule, the paper suggests, religious and community leaders often sanctioned the practice of community-led dispute resolution, grounded in Islamic principles of mediation and arbitration, to settle disputes without recourse to government courts. Ultimately, the routines of Muslim non-state adjudication formulated in South Asia were transposed through the dynamics of migration to the UK, where they continue to be visible in faith-based dispute resolution forums and practices.
\end{abstract}

Keywords: Alternative Dispute Resolution; British Islam; South Asian Islam; shari'ah councils; mediation (sulh); arbitration (tahkim)

\section{Introduction}

In my role... I have tried to deal with problems themselves and to mediate between people ... we are developing, on a daily basis, understanding about what a marriage is, what the ingredients of marriage are, how to deal with our partners, and so on ... We are not here to investigate [a husband's] story or [a wife's] story. We are here to see if their marriage is workable, and if it has the right ingredients of trust, respect [and] compassion between the parties. We are not there to judge them... we are there to help them, both men and women, to move on with their lives. ${ }^{1}$

With these words, Amra Bone, a panellist on the shari 'ah council attached to the Birmingham Central Mosque, describes some of the marriage and family counselling and conciliation work that she and other members of the council provide for its clients. ${ }^{2}$ Bone's words here invoke several core principles that underwrite dispute resolution according to shari 'ah. First, that dispute resolution should be conciliatory in tone: it should bring conflicting parties together whenever possible and strive to seek mutually acceptable solutions that can avoid acrimony and sustain relations. Second, that the search for a resolution should be flexible, 
sensitive to the given situation and the parties involved. And third, that the parties themselves should be encouraged to find a resolution, rather than going to an outside body such as a court. As Bone puts it, shari 'ah council members are "not there to judge", but to seek solutions without formal adjudication wherever possible.

Underpinning Bone's words are two legal principles of Qur'anic roots: sulh (mediation) and tahkim (arbitration). These have become part of the inventory of concepts upon which has been constructed a network of alternative dispute resolution forums among British Muslims. This paper is an attempt to explore some of the language and mechanisms that characterise these practices of Islamic extra-legal settlement, by framing them against the background of their longer term roots. In particular, it seeks to unravel the links of these practices to colonial India, and suggests the transposition of a particular model of Muslim dispute resolution from colonial-era South Asia to contemporary Britain.

\section{Sulh and Tahkim: The Principles of Alternative Dispute Resolution in Modern Islam}

It is an often voiced maxim that, while Western law is based around the application of objective principles and weighing of competing interests between parties, shari'ah emphasises contextual application and places greater emphasis on the principle of seeking conciliation via the negotiation of consensual agreement. Central to procedures of dispute resolution according to shari 'ah are the principles of sulh (mediation) and tahkim (arbitration). Each is mutually distinct: sulh denotes the attempt by a third party to encourage conflicting parties to move towards their own settlement of a dispute, ${ }^{3}$ while tahkim refers to a third party taking responsibility for evaluating a dispute and deciding upon the correct outcome. ${ }^{4}$ However, Islamic scholars as well as academics admit that the two blend into each other in practice, to the extent that some speak of the hybrid concept of Mediation-Arbitration (or "Med-Arb") to convey the fluid nature of the duties taken on by a third-party negotiator. ${ }^{5}$

Both in the Qur'an and during the formative period of Islam, the principles of mediation and arbitration were adopted as the preferential mechanisms of settlement. As studies have shown, they were drawn from pre-Islamic custom, and are alluded to in many of the sayings and deeds attributed to the Prophet, the Caliphs and the Imams alike. Indeed, many ahadith reveal how these legal mechanisms were employed by the Prophet and the Companions as the foremost methods for settling disputes right up until an Islamic judicial system and the notion of executive judgement (known as qada) was finally consolidated in the Abbasid era. ${ }^{6}$ In this sense, sulh and tahkim alike carry the sense of being non-judicial or pre-judicial mechanisms, designed to resolve conflicts in the absence of judicial authority and negotiated through community agreement. ${ }^{7}$

This said, despite the non-judicial background of these principles, Islamic regimes throughout history have co-opted these mechanisms into the workings of state practice. In the Ottoman imperial system, for instance, qadi courts (Islamic courts) often themselves enacted sulh and tahkim to broker solutions between parties as alternatives to the more disciplinary or penal exercise of qada (judgement). Mediation and arbitration were used to resolve a range of civil, commercial and family disputes, and could either be performed by the Ottoman qadis themselves or assigned to local representatives acting on their instructions. ${ }^{8}$ 
Similar practices have carried over into the legal procedures of the Muslim-majority nations that emerged out of twentieth-century decolonisation. Many contemporary states in the Islamic world have arbitration acts or codes of civil and commercial procedure elaborating these principles. Most significantly, arbitration and mediation have been carried across into Islamic family law as applied in many postcolonial nations. For instance, codes of personal status (i.e. family law codes) of Arab states including Egypt and Jordan specify that arbitrators should handle marital breakdowns, endeavouring to bring about reconciliation or fair separations. Likewise, these states empower a range of judicial institutions, including family courts and qadi-run Islamic courts, to undertake family mediation or provide counselling services. ${ }^{9}$ Similarly, in Pakistan under Section VII of the Family Laws Ordinance (1961), divorce proceedings are handled by union councils - official local government bodies, which formally appoint arbitrators to intervene and seek reconciliation between spouses as compulsory measures before a divorce process can be initiated. ${ }^{10}$

However, while in much of the contemporary Muslim world arbitration and mediation have been thus co-opted and developed by the judicial institutions of the state as executive powers, these mechanisms have been applied in different ways by Muslims in non-Muslim countries. Here, the pre-judicial or non-judicial heritage of sulh and tahkim have made them an obvious reference point for Muslim minorities who have endeavoured to follow shari 'ah laws in the absence of an Islamic judicial structure. For them, these Qur'anic principles can be used as guidance at community level, where they can provide a model of practice for modern community-based dispute resolution bodies, especially in the domain of family law. ${ }^{11}$

\section{Islam and Alternative Dispute Resolution in Contemporary English Law}

The last few decades have seen the emergence of what one study characterises as "a complex informal network and hierarchy of Muslim dispute fora in Britain." 12 While informal arbitration and mediation services have been provided by individual imams or community leaders since the early waves of Muslim immigration to the UK in the 1950s-60s, these quasi-legal practices have, in later generations, increasingly been embodied in the institutional forms of dedicated community organisations. A range of alternative dispute resolution (henceforth: ADR) centres and forums now offer services of family counselling, guidance and dispute settlement for Muslim clients. By handling disputes through informal family or community conciliation, they seek to reach durable settlements that are sensitive to the particular circumstances of their clients, and which might reduce the need for the more traumatic experience of formal litigation. ${ }^{13}$

Among these are a range of local, informal Muslim family mediation and marriage counselling services. These include the An-Nisa Society, established in London in 1985 to promote the welfare of Muslim families; Sakoon, another London-based team of Muslim counsellors and psychologists established in 2006; ${ }^{14}$ and the Barefoot Institute, an organisation led by the imam Ajmal Masroor that propounds to combine "traditional Islamic guidance" with "cutting edge psychology and relationship science." "Equivalent provisions are also available from phone-based services, including the Muslim Women's Helpline (a telephone-based service established in 1989), the more recent comparable resource centre Amina, and various online portals. ${ }^{16}$ 
Of higher profile are a range of so-called 'shari 'ah councils', which have been the subject of their own body of dedicated literature. While best known for issuing Islamic divorces ( $k$ hula ), their work - as is shown in the reflections quoted at the beginning of this paper - also routinely includes the mediation and arbitration of family disputes. Notable examples include the Islamic Shari'a Council (founded in Leyton, East London in 1980) and the Muslim Law (Shariah) Council (MLSC, founded in Ealing in the 1980s), both of which advertise wideranging ADR services including family and spousal mediation. ${ }^{17}$ There is also the Muslim Arbitration Tribunal of Nuneaton, which offers a systematised arbitration legal service to cover civil and commercial disputes, as well as mediation in family affairs (discussed below); and the Birmingham-based Islamic Council, a forum dedicated to mediation and arbitration, which offers a wide-ranging array of services including an established "nikah guidance programme" developed by British muftis and shaikhs to offer marital counselling according to shari "ah. ${ }^{18}$

These examples demonstrate the breadth and variety of the ways in which community organisations have harnessed the legal technologies of mediation and arbitration from within the Islamic tradition in order to serve community demands. The importance of these legal strategies was affirmed in the 2018 report of the government review into shari 'ah law in England and Wales, which argued that shari 'ah councils and other community organisations recurrently invoke the principles of mediation and arbitration, and do so according to a "loose definition" by which they can refer to processes of reconciliation, consensus-building and a range of other services. ${ }^{19}$ In this way, Islamic principles of sulh and tahkim have been harnessed as the legitimising basis for a wide array of counselling, conciliation and dispute settlement institutions.

The range of Muslim ADR forums in Britain has led some analysts such as Ihsan Yilmaz to conclude that British Muslims "have withdrawn from state institutions and developed their own methods of alternative disputes resolution which operate on both an official and unofficial level." ${ }^{20}$ Muslim ADR bodies, by this reading, are evidence of an "unofficial legal pluralism" at work in Britain, in which Muslims choose to resolve their problems via approaches to community bodies rather than government courts. ${ }^{21}$ Yet, this rather binary "separate spheres" approach understates the extent to which Muslim conciliation processes may work simultaneously across both official and unofficial domains of law. In practice, British Muslim communities have developed a working form of legal mobility across formal and informal legal bodies by which individuals might consult community forums like shari'ah councils, mosques or biradaris (community associations) either instead of, or alongside, state or official authorities such as family solicitors, courts or police. ${ }^{22}$

Some analysts have treated the apparent vibrancy of faith-based arbitration in the UK (embodied by, for example, the Jewish beth din as well as the Muslim bodies discussed here) as partly attributable to the relatively flexible civil law system in England and Wales, which allows considerable scope for parties to handle disputes via bespoke mediation or arbitration procedures. Indeed, one of the most striking features of the growth of faith-based ADR forums in recent decades is that their rise dovetails with a series of developments in English law which have placed more emphasis upon out-of-court dispute settlement. ${ }^{23}$ The apparent ability of English civil law to accommodate processes of non-judicial arbitration and mediation means that some Muslim ADR forums have managed to bring their dispute resolution mechanisms into the purview of the legal system. 
The most striking example is perhaps the Muslim Arbitration Tribunal (MAT), a nongovernmental legal service based in Nuneaton that was established by an Islamic scholar, Faiz al-Aqtab Siddiqi, in 2007. ${ }^{24}$ The MAT claims to provide what it calls "a viable alternative for the Muslim community seeking to resolve disputes in accordance with Islamic Sacred Law." "25 It is comprised of both Islamic scholars and legal professionals trained in English law, and hence presents its arbitration practices as working in full engagement with both English civil laws and the shari ' $a$ h. When it handles civil or commercial disputes, the MAT operates under the Arbitration Act of 1996, meaning that its decisions are legally recognised and can be enforced through the courts. ${ }^{26}$ Drawing from Islamic principles of dispute settlement, the organisation contrasts the "adversarial procedure" and "aggressive atmosphere" of the courts with its own services, which are said to negotiate affordable, efficient decisions that sustain channels of communication between the parties and avoid irretrievable breakdown in relations. $^{27}$

In more recent years, there have also been government initiatives to expand the role of mediation and arbitration beyond civil litigation, and into English family law in particular. ${ }^{28}$ This has taken place in response to modern shifts in family relationships and in order to spare parties from the strains of litigation, so long as these arbitration mechanisms operate under ultimate oversight by the legal system. ${ }^{29}$ Since most Muslim dispute resolution forums focus their activities upon family issues such as marriage and divorce, their decisions do not have recognition in court (unlike the decisions of the MAT on civil and commercial matters discussed above). Despite this, both the "formal" judiciary and "informal" quasi-legal faithbased forums have to some degree converged around a mutual acceptance of the benefits of arbitration and mediation. As some authors have noted, these legal mechanisms may comprise one of the closest points of potential accommodation between the legal-ethical principles derived from shari 'ah and the stipulations of English family law. ${ }^{30}$

\section{The South Asian Origins of Muslim Alternative Dispute Resolution}

Many studies of the kinds of Muslim ADR institutions named above have framed them as having taken shape within the largely flexible framework of family law in England and Wales, and its capacity to accommodate faith-based dispute resolution. ADR bodies are thus treated through a largely contemporary lens: as responses to the contemporary diasporic context; as attempts to navigate changing social practices by second- and third-generation British Muslims; or as products of contemporary polities of multiculturalism or legal pluralism. ${ }^{31}$ All such explanations, in different ways, thus view these bodies in terms of their apparent newness. ${ }^{32}$ However, a further notable feature of many of these ADR forums and practices is that they have often been developed chiefly by Muslim communities of South Asian ancestry. On one level, this feature is not surprising, given that a majority of British Muslims are of South Asian origins, most being the descendants of immigrants from the Indian subcontinent in the 1950s-60s. Yet, a glance at the management, clientele and practices of these ADR forums reveals their substantive links with Islamic legal norms and cultural practices inherited from the Indian subcontinent.

For instance, some of Britain's major ADR forums have arisen out of South Asian schools of Islamic thought. The Islamic Shari'a Council, one of the best-known shari'ah 
councils which is situated in east London and has been running since 1980, was inspired by the Deobandi and Ahl-i-Hadith schools, two major reformist movements of late-nineteenth century north India. ${ }^{33}$ The MAT, likewise, is attached to the so-called Hejaz community, a Sufi-inspired organisation founded in the line of Naqshabandi Sufis linked to the hinterlands outside Lahore. More generally, it is sometimes considered as loosely affiliated with the "Barelwi" movement: another major movement of Islamic renewal of colonial-era northern India rooted in lines of Sufi shaikhs. ${ }^{34}$

Likewise, the majority of clientele who seek the assistance of these fora are British Muslims of South Asian origins. This is predictably the case for those forums named above, which have an identifiably South Asian legal orientation and leadership; but it is also true for councils such as the Muslim Law (Shariah) Council which, while founded by an Egyptian cleric, Zaki Badawi, has chiefly come to serve Pakistani-origin communities, and has had a historical predominance of South Asian-origin scholars and staff. ${ }^{35}$ These councils sometimes adopt Urdu as well as Arabic or English as their working language for some of their clients; and since they often find themselves handling issues particular to South Asia (for example, transnational marriages among British-Pakistani families ${ }^{36}$ ), they have needed to cultivate expertise in Pakistani as well as English marriage law and Islamic family law. ${ }^{37}$ Today, most major Muslim ADR bodies claim to be open to clients of all maddahib (legal schools) and all ethnic or cultural backgrounds ${ }^{38}$; nevertheless, the origins, expertise, leadership and clienteles of these councils often identifiably rest in South Asian brands of Hanafi Sunnism. Likewise, many smaller Muslim organisations that engage in local mediation and counselling services are identifiable to communities bound by ties of South Asian ethnicity and kinship, whether Bangladeshi, Mirpuri or Gujarati.

The explicitly South Asian ethos of some of these forums might lead us to recall John Bowen's discussion of contemporary shari 'ah councils. In contrast to some other studies of these councils that emphasise their newness as mentioned above, Bowen emphasises the need to look at their longer-term origins, and in particular, the historical and cultural pathways that link them with South Asia. Modern shari 'ah councils, he suggests, manifest "remembered social forms" that were inherited from a South Asian cultural background, and were thereafter "transposed to Britain" and "adapted to the new environment." 39 The reasons for this, he argues, lie in the pattern of South Asian chain migration to Britain, which was marked by the movement of communities defined by kinship, and their concentrated settlement in certain areas. This pattern allowed for the replication of Muslim religious and cultural institutions that reflected their South Asian points of origin, and meant that British Muslim religious institutions such as mosques, religious schools and shari 'ah councils have continued to exhibit identifiably South Asian-origin religious practices and orientations. ${ }^{40}$

This paper suggests that, rather than solely tracing religious institutions (e.g. shari 'ah councils) in this way, the same might be said of particular legal-ethical practices, such as community-based dispute settlement, that have been appropriated by Islamic scholars to handle community affairs in contemporary Britain. I argue that contemporary applications of Muslim ADR similarly represent remembered forms of community regulation that were formulated in colonial-era South Asia and were, thereafter, recreated in Britain. Both prior to and after partition, Muslims in the subcontinent often became accustomed to handling community affairs outside of the structures of the government courts. As such, they established a range of cultural 
mechanisms and religio-legal institutions, grounded in the language of Islamic mediation and arbitration, that provided an infrastructure to adjudicate Muslim family affairs separately from the formal legal system. A full understanding of Muslim ADR in Britain, therefore, entails investigation into the longer term antecedents of these patterns of non-state dispute resolution among Muslim communities in the Indian subcontinent, especially during the late-colonial and early-postcolonial decades.

\section{Muslim Alternative Dispute Resolution in Colonial-era South Asia}

On first impressions, the suggestion that colonial-era South Asia was a site notable for the production of new cultures of non-state Islamic dispute resolution may seem surprising. A substantial proportion of academic literature on the handling of Islamic family laws in colonial India has emphasised the colonial courts' assertion of their jurisdiction over Islamic family laws. From the late-eighteenth century onwards, and especially after the establishment of the British Raj in 1858, the British legal system generated a corpus of law known as AngloMuhammadan Law: a hybridised body of remodelled Islamic laws, based on a mixture of case law and a body of translated legal texts, that could be adjudicated within the colonial court system. This body of jurisprudence was limited to Islamic laws of family (or, as often called in India, "religious personal laws"). The colonial state's rationale for maintaining this distinct system of family laws for Muslims and other subject populations lay in commitments to adhere to a policy of "non-interference" in the religious lives of their subjects. ${ }^{41}$ Yet, the development of this body of law also gave the colonial judiciary (staffed by both British and Indian judges) legal jurisdiction over Muslim family affairs. Moreover, it meant that a class of colonial legal professionals supplanted the muftis and qadis - the religious officials who historically had taken charge of adjudicating disputes in Mughal and early-colonial India. ${ }^{42}$

Although well-established, this narrative has been propounded by studies that chiefly rely upon formal legal sources - such as statutory laws and court records - and thus emphasise the handling of Islamic family laws within the colonial judiciary. As such, this narrative does not acknowledge the equally vibrant, developing world of community-based, quasi-legal forums within some Muslim populations, which often existed in deliberate autonomy from the official judicial system. Several features of the legal polity of British India - the relative thinness and cultural remoteness of the judicial system to most Indian subjects; the administration's reluctance to "interfere" in religious institutions whenever they presented no threat; and the absence of any explicitly codified Islamic law or structure for adjudicating it created an environment in which community-based dispute resolution systems could be established and operate relatively freely.

For these reasons, colonial India from the later decades of the nineteenth century onwards became host to a range of Islamic socio-religious organisations created to assist ordinary Muslims in resolving their interpersonal disputes without resorting to the courts. Since the 'ulama (Islamic scholars) remained highly ambivalent about decisions on Islamic law being made by colonial courts (and in particular, by non-Muslim judges), ${ }^{43}$ they began to develop structures by which Muslims could adjudicate community matters outside of the official legal system. In the later decades of the nineteenth century, many schools of 'ulama established quasi-legal services, dispensing advice and decisions on points of shari 'ah to Muslims who, 
by choice or necessity, did not take their disputes to the government courts. Chiefly, these ulama operated within the remit of Islamic family law, such as in marriage or divorce matters, and sought to resolve these conflicts via community-led conciliation processes grounded in Islamic legal principles.

\section{Resolving disputes through fatwas}

One mechanism applied to assist Muslims with handling their matrimonial and family matters without the need for court intervention was ifta': the issuing of fatwas, or extra-legal Islamic decisions that could be acted on voluntarily by those who elicited them. By the latter half of the nineteenth century, and adapting to the revised role hoisted upon them in colonial India, the 'ulama made unprecedented efforts to direct their legal expertise towards the Muslim lay population, making use of new technologies of communication and print in order to do so. ${ }^{44}$ For example, by the $1880 \mathrm{~s}$, scholars attached to the important madrasa at Deoband were issuing advisory edicts to other scholars and lay clients, and by 1892-93 a systematic dar-alifta' (fatwa office) had been set up, able to receive and respond to questions from lay Muslims - a large proportion of which related to matrimonial and family matters - and preserving records of its own edicts for future reference. ${ }^{45}$ Over the following decades, most of the largest South Asian madrasas established offices for dispensing fatwas in response to enquiries from petitioners.

Since they were attempting to resolve disputes without recourse to judicial means, 'ulama from this period often turned to the principles of mediation and arbitration as the chosen mechanisms to ensure fulfilment of their decisions. Frequently, muftis advised in their fatwas that divorce proceedings, marital reconciliations, distribution of inherited property and other such transactions should be overseen by local community mediators or arbitrators, so that acceptable solutions could be arrived at. ${ }^{46}$ Sometimes, these 'ulama would take on such functions themselves; very often, however, they instructed that local elders or relatives should be appointed to supervise the fair handling of such delicate interpersonal affairs, taking on the role of interlocutors or arbitrators.

Evidence for this can be seen in a fatwa produced by Rashid Ahmad Gangohi (18261905), the most influential mufti of the Deobandi movement's first generation. ${ }^{47}$ In the later years of the nineteenth century, a petitioner asked him how Muslims should resolve their disputes in a place where there was no official qadi (Muslim religious judge) appointed to serve them - as, by implication, was the case in British India. He suggested that, should two persons be unable to settle a dispute between themselves, then they should decide upon a "hakam" (an arbitrator or mediator), who they both trusted to have knowledge of the shari 'ah, to handle the dispute. If this procedure was followed, then the order (hukum) given by this person would be "equivalent to the ruling of a judge" (qadi), regardless of the fact that his decision would have no legal force. ${ }^{48}$ Republished in one of the colonial period's most influential compendia of fatwas, this set a model for community-based resolution that did not depend on access to executive authority but allowed pious individuals to select their own equally pious interlocutors.

This model of non-state mediation and arbitration - alternative dispute resolution in all but name - was ever more specifically elaborated by other muftis over the subsequent decades. 
Ahmad Raza Khan (1856-1921), the prolific founding mufti of the "Barelwi" school, produced a range of fatwas around the 1900s-1910s suggesting that, when the state was unwilling to sanction the appointment of a qadi, members of the Muslim community itself could select such a figure to take on this duty in order to settle community disputes outside of the government courts. ${ }^{49}$

As with his Deobandi counterparts, Ahmad Raza Khan's fatwas often insinuated the role of a mediating or arbitrating interlocutor to ensure the implementation of legal advices on issues such as, for instance, oversight of divorce procedures; supervision of the behaviour of restive spouses; settlement of inheritance or property disputes; or intervention in conflicts over the management of mosques or endowments. ${ }^{50}$ In some fatwas, Ahmad Raza Khan spoke explicitly of two wilayas (authorities or jurisdictions) in existence in India. One was an executive authority, or the power of command (wilayat-i-mujbarah), held by the political or military rulers, that controlled national or customary affairs. The other was a moral or godly jurisdiction (wilayat-i-diniya or wilayat-i-shari 'ah), that was held by Allah and remained under the interpretative custody of religious experts. ${ }^{51}$ Like most Indian 'ulama of his generation, Ahmad Raza Khan was clear that it was the individual's responsibility under Allah to obey the law of the land in political and national questions, but equally, to follow the path of shari 'ah in the non-political sphere of personal conduct and conscience.

A generation later, Mufti Muhammad Kifayat Ullah (1875-1952), another graduate of Deoband and one of the most prolific and influential South Asian muftis of the twentieth century, produced so many fatwas dealing with the non-judicial adjudication of interpersonal conflicts that the theme of "third-party" mediation or arbitration (salsi) is dealt with as a specific section in the compendia of his edicts. Through a series of fatwas issued in the 1920s1940s, he suggested that community Islamic legal forums (shari ' panchayat) could be used to handle disputes or divorces in place of the courts; that local bodies (panchayati tariqe) could be considered as authoritative to resolve arguments; and that, in the absence of an official qadi, it was possible for a qualified 'alim (scholar) to act as a third-party mediator, arbitrator or judge (respectively salis, musleh, hakam) to settle disputes. ${ }^{52}$ Kifayat Ullah's elaboration of the precise protocols of local mediation and arbitration procedures illustrates how the issuing of fatwas also demanded a concomitant effort to establish the local structures by which these fatwas might be implemented within the communities to which they applied.

Resolving disputes through dar-al-qadas (shari'ah councils)

In addition to the dispensation of fatwas, other 'ulama began to re-appropriate the role of qadi (religious judge), a role that - as an official appointment - had been abolished by the British government in $1864 .{ }^{53}$ Lacking a qadi, community leaders argued, Indian Muslims had no authority able to adjudicate their marital issues, release women from bad marriages, or settle community disputes. ${ }^{54}$ In this context, some Muslim leaders sought to depart from the received wisdom of legal texts such as al-Hedayah, that argued that a qadi could only be appointed by the ruler, and found ways for the community itself to appoint its own qadis to dispense these essential services.

A key example of this was appointment of a non-state qadi that occurred at Deoband. The school's founding shaikh and scholar Muhammad Qasim Nanautawi (1832-1880), it is 
said, understood the need for "matters of personal law to be acted upon according to shari 'ah principles", and so he appointed Muhammad Ya'qoob (1833-1884), the school's first head tutor and his cousin, as a qadi (religious judge). However, this was "the office of qadi in unconventional form" since, in a break from the conventional practice in pre-1860s India, the appointment was now authorised by a religious scholar rather than the government. ${ }^{55}$ In effect, the school of Deoband thus pre-empted the existence of an independent infrastructure of community justice, giving local Muslims the option of taking their matrimonial or interpersonal disputes to a religious judge rather than to a government magistrate.

Building upon early appointments of individuals into the unofficial but locally commanding position of qadi, later years witnessed the growth of networks of shari'ah councils, which transposed some of this quasi-legal authority from the individual scholar to the hosting institution. Bearing an indirect resemblance to those operating in England today, these were non-state, quasi-legal forums run by 'ulama that dispensed shari'ah-based qada'iyas (judgements) on specific issues that fell within the domain of personal law. While their main venture (as in England) was issuing Islamic divorces, these forums also offered third-party resolution of interpersonal disputes.

The most significant such court network was a cluster of forums created by the Amarati-Shari'ah, a Deobandi-inspired religious organisation founded in the Indian state of Bihar in 1921 to provide shari'ah-based guidance to the community. ${ }^{56}$ Upon its foundation, the organisation set up half a dozen semi-autonomous dar-al-qadas (shari 'ah councils) across the state, which handled intra-community disputes under the supervision of a non-official qadi. These qadis, the organisation argued, were essential for administering the many legal affairs of Muslims that the state could not: enacting divorces, handling marital disputes or requests for the validation or restoration of marriage, and solving arguments about inheritance or property, for example. ${ }^{57}$ The number of these non-state courts grew over subsequent decades, with the organisation now sustaining several dozen such institutions in several provinces of eastern India. ${ }^{58}$

Operating in small towns and through local kinship networks, the aim of these dar-alqadas was to deliver straightforward, culturally acceptable and flexible settlements to intracommunity disputes. As unofficial legal forums, they did not command the executive powers of the state, but often operated through the exercise of mediation and arbitration. Often, their non-official "qadis" would take on third-party duties such as urging the restoration of marriage, pushing spouses to amend their behaviours, or overseeing divorce proceedings. In other cases, the qadi might assign duties of arbitration or mediation to local community elders. A pious male relative, village headman (panch), local imam or other similar figure could be appointed as an arbitrator (hakam) or a guarantor (zaamin) so that the decision reached by a qadi could be implemented on the ground. ${ }^{59}$

Together with a range of other dar-al-qadas created both before and after independence, India is now host to a plethora of such institutions today, all of which practice the non-state adjudication of shari 'ah-based affairs within India's highly pluralised legal landscape of personal laws. By the mid-twentieth century, these dar-al-qadas saw an ever greater level of procedural sophistication, by which time their major proponents had set in place a clear series of regulatory mechanisms for these courts, and fully outlined the protocols ( $a d a b)$ to be followed by the appointed qadis. ${ }^{60}$ While never contesting court jurisdiction, these 
Muslim ADR bodies and non-judicial "courts" continue to operate in a framework of legal pluralism in which they share responsibility for legal adjudication with a range of other state and non-state forums. ${ }^{61}$

The examples given above indicate the limits to speaking - as have some scholars - of the colonial "governance" or the "jural colonisation" of Islamic law in colonial India. ${ }^{62}$ While the fact has often been forgotten, a large proportion of Muslim family and community disputes continued to be settled not by the British courts, but through religious, kinship or communitybased dispute resolution bodies. These included a range of new institutions, including dar-alifta's to provide advisory guidance, and dar-al-qadas where religious judges could deliver shari'ah-based verdicts to petitioners. Fatwas and qada'iyas issued in colonial India reveal how the 'ulama were formulating a binary construction of domains or jurisdictions of law (known as wilaya) - one of state and one of shari 'ah - that in some senses reflected colonial boundaries between secular and religious affairs. This model articulated the nature of legal selfgovernance in the Muslim community in a colonial context, and set a framework for the interpretation and implementation of shari 'ah laws by community-based forums.

\section{Elaborating a Model of Muslim Dispute Resolution in South Asia}

The paradigm of Muslim dispute resolution that developed in the Indian subcontinent in the late-colonial era was a pragmatic response to the absence of an authoritative Islamic judiciary, and the need for Muslims to work within the framework set by the colonial state to resolve their disputes internally. However, since all the quasi-legal institutions discussed above had no formal legal recognition, greater emphasis fell upon intra-community mediation and arbitration as the preferable means for exacting intra-community settlements. As such, the 'ulama and other religious leaders in early twentieth century India had to compound their efforts in setting up these community forums with the articulation of models that justified and elaborated the principles of non-state dispute resolution in Islam. This meant, firstly, revisiting historical examples of these arbitration and mediation mechanisms in practice; and secondly, revising stipulations of fiqh (jurisprudence) to adjust the laws of dispute resolution to the new context.

A common trend among scholars in the early-twentieth century was to look beyond traditional stipulations of the law schools concerning the methods of judgement (qada), and turn back to the salaf, the Companions of the Prophet, as providing a model for resolving conflicts prior to the later creation of an Islamic judiciary. Some scholars looked to the second Caliph, 'Umar ibn al-Khattab, on the basis that 'Umar is the source of perhaps the earliest recorded tradition commanding that a judge or arbitrator should prioritise reconciliation or interpersonal settlement over judicial intervention wherever possible. ${ }^{63}$ Just one example was a treatise entitled Al-Qada fi al-Islam ("The Method of Adjudication in Islam") produced around 1910 by 'Abd al-Islam Nadvi, a scholar of the Nadva't al-'Ulama seminary at Lucknow. The text exalted the arbitration skills of the second Caliph, 'Umar ibn al-Khattab, who was especially renowned for his ability to settle conflicts within the early ummah. 'Umar, the author writes, was a skilled arbitrator, who could process the details of a case with the same skill as a butcher could separate flesh from bone. ${ }^{64}$ Others, similarly seeking a prototype for the role of 
the modern qadi, have also looked back to 'Umar as community conciliator, a figure able to negotiate just settlements and ensure the dispensation of justice to disadvantaged parties. ${ }^{65}$

Simultaneously, there was a renewed attempt to emphasise and explain the methods of arbitration set in the Qur'an. Numerous fatwa collections and legal treatises emphasised the contemporary need for Muslims to reflect upon the so-called ayah-al-tahkim (4:35) - which outlines instructions for the appointment of arbitrators for each party to solve a dispute - as guidance for a Muslim community that lacked access to an Islamic judiciary. ${ }^{66}$ Scholars elaborated the meaning of this ayah by relating it to illustrative stories from the time of the Companions. To give just one example, 'Abd al-Samad Rahmani (d. 1973), an influential scholar attached to both Deoband and the Amarat-i-Shari'ah and deeply involved in the construction of dar-al-qadas in northern India, read this ayah in the light of a story relating to the fourth Caliph 'Ali ibn Abi Talib. As recounted by Rahmani, a couple experiencing marital difficulties had approached 'Ali; 'Ali then commanded that an arbitrator (hakam) should be appointed from the respective families of each of the spouses, and instructed that: "if you find that you can bring them back together, then do so, but if you find that they should be separated, then do so." ${ }^{67}$ The representatives of each partner simply had to be male, mentally competent, just and righteous, cognisant of their duties, and attentive to the obligations of reuniting and separating spouses. The couple would have to consent to these representatives being charged with the decision; but then would be bound to accept the outcome. ${ }^{68}$ In other words, the settlement (whether it be reconciliation or separation) could be overseen by local community representatives taking charge of the dispute, and without an official qadi being present at all.

This model of non-state dispute resolution has persisted in all South Asian countries post-independence. It is perhaps most obvious in independent India, where the state has developed a so-called "shared adjudication model" by which non-state legal forums have been given a large degree of autonomy by the state, as part of a wider strategy of multicultural integration and recognition of minority rights. ${ }^{69}$ In this context of operative legal pluralism in family laws, a range of Muslim dispute resolution forums, including dar-al-qadas, the offices of muftis or imams, community biradaris (brotherhoods) and shari'ah panchayats (local religious councils) continue to handle intra-community disputes outside of official institutions, and share these duties with family courts and an array of other official bodies. ${ }^{70}$

But a similar pattern of non-state dispute resolution has also remained apparent in South Asia's Muslim majority states, even though these states have historically pushed harder than India to bring Islamic family laws under legislative control. In Pakistan, many intra-community disputes (over marriage or property, for instance) continue to be handled by village panchayats and other non-official bodies. ${ }^{71}$ Moreover, non-state, unrecognised shari 'ah courts operate in parts of Pakistan, such as rural Punjab and Khyber Pakhtunkhwa. ${ }^{72}$ Institutions such as these have endured in rural areas, despite the attempts of the state to consolidate its jurisdiction over family laws via the Family Laws Ordinance of 1961, and despite subsequent attempts to prohibit or criminalise the running of panchayats. The same could be said of Bangladesh, where informal tribunals and village courts have played important roles outside an inaccessible and unaffordable formal legal system. ${ }^{73}$

The practice of Muslim non-state dispute resolution in South Asia, therefore, has persisted. Indeed, it has been more enduring and resilient across South Asia than, say, in most contemporary states in North Africa or Arab West Asia, where judicial and legislative 
command over the adjudication of Muslim laws has been historically stronger, and where dispute resolution outside of state purview has been more restricted. There are many reasons why this may be the case. However, among these is the raw fact that the colonial state in India had - under the guiding principle of "non-interference" - allowed considerable freedom for the operation of systems of non-state or semi-official adjudication. Colonialism thus lay the ground for an environment in which Muslim community leaders were able to offer shari 'ah guidance in community disputes, so long as they did not impinge on the authority of official laws, and thus they built up an infrastructure with which to do so. Not only have these cultures continued into postcolonial South Asia, but they have - through the dynamics of migration - gone on to shape the landscape of Muslim legal life as it exists in modern Britain.

\section{Alternative Dispute Resolution and "Angrezi Shari'at": Some Further Reflections}

This paper has identified close resemblances between the kinds of non-state legal forums that emerged in the Indian subcontinent in the early twentieth century (and which have continued to exist in all South Asian countries) and the kinds of faith-based dispute resolution bodies that have emerged in modern Britain. Under colonial rule in India, mechanisms of intracommunity settlement by mediation or arbitration took on new forms in response to the necessities dictated by the abolition of religious judges and the wider framework of colonial legal jurisdiction. Thereafter, equivalent mechanisms have found space in the patchwork of British Islam, embodied in a range of non-state quasi-legal practices. As noted above, these forms of arbitration and mediation were originally practiced by religious and community leaders and baradaris within clearly demarcated immigrant communities; increasingly in the last three or four decades, however, they have taken shape around dedicated forums which dispense these services.

British Muslim ADR forums continue to be dominated by South Asian leaders, language and clients. They share with their South Asian antecedents a rhetorical and practical emphasis on the need for dispute resolution by intra-community agreement, and a similar focus on the restoration of collective harmony. They also operate within Hanafi-centred orientations that reflect various reformist movements of South Asia, such as the Deobandi and Barelwi movements (although, even more than their parent institutions in South Asia, the institutions in Britain have encouraged the selective consultation of other legal schools and application of modernist methods where necessary).

Moreover, in their own distinctive ways, the dispute resolution bodies of colonial South Asia and post-imperial Britain are both attempts to respond to their respective minority predicaments, with Muslim community leaders in each of these contexts establishing institutions intended to preserve Muslim life outside the institutions of the state. In both cases, these leaders have argued that when the executive cannot provide an Islamic judiciary committed to adjudicating interpersonal disputes according to shari'ah laws, it falls to community leaders - shaikhs, muftis or non-state "qadis" - to assume these duties of dispute resolution for the public good.

This discussion has several implications for the study of Muslim dispute resolution

processes in contemporary Britain. For example, it indicates the apparent resemblances between the colonial legal presumptions at work at in British India and in modern Britain. In 
both contexts - whether the colonial approach of "non-interference" or the "multicultural" polity of modern Britain - there has been an implicit or explicit recognition of the role for dispute resolution mechanisms outside of the courts, and the possibilities offered by ADR processes for more harmonious, culturally authoritative settlements. ${ }^{74}$

From another direction, this paper also carries a message regarding the migration of cultural norms of dispute resolution. The fact that legal institutions and practices were so readily transposed from colonial India to modern Britain may reflect a migration pattern that allowed the production in situ of cultural institutions and norms. Arguably, this has led to an ongoing sense among some British Muslim communities of distance from the law, and the desire to resolve disputes internally without consulting the courts. As one contemporary British imam has described it, earlier generations of South Asian immigrants were largely "left to integrate" by the state, and reciprocally, continued to rally around imports from a culture "back home." The ongoing preference of some Muslims for community-led dispute resolution, he argues, is (like, incidentally, the preference of many for nikah-only marriages) a symptom of this embedded, long-term sense of Muslim autonomy from the structures of the state. ${ }^{75}$

Academic opinion has been divided over the ramifications of the widespread practice of alternative dispute resolution in family matters by British Muslims. As noted, some analysts have praised out-of-court mediation and arbitration as a general principle, including that practised by faith-based tribunals. Arguments used in support of these forms of dispute resolution include assertions that, by comparison with litigation, they may be quick; affordable; adaptable to the needs of the litigants; private (by contrast with the "public" nature of courtrooms); less adversarial and more conciliatory in approach; and embedded in the cultural values of minority communities. ${ }^{76}$ Others, however, have expressed reservations. Observers of Muslim dispute resolution have sometimes queried the boundaries between ADR as a process of facilitating parties to reach their own resolutions to disputes (better characterised as mediation), and one in which a third party interlocutor takes a deciding role themselves (better characterised as arbitration). As noted above, the boundaries between these two categories can be ambiguous in practice. Thus, while Muslim dispute resolution may be presented as a process of consensus-seeking, it may in fact empower community leaders to impose their decisions upon vulnerable clients. ${ }^{77}$

A linked concern is that, by allowing disputes to be resolved through negotiation within kinship or local networks, ADR might entrench existing structures of power within those groups. As the contemporary legal activist Aina Khan has put it, mediation "does not have good outcomes for the weaker party." 78 ADR may thus disadvantage the more exposed side in a conflict, and there are concerns that Muslim ADR processes especially may often benefit husbands over wives. This suggestion evinces the view of some scholars that such forums are covert attempts to reassert patriarchal authority and exert social control over Muslim women. ${ }^{79}$ Moreover, many legal specialists have expressed fears that an over-reliance on ADR can encourage isolation from the conventional legal processes that are best equipped to protect the vulnerable. ADR, in other words, risks becoming an alternative to the official legal system rather than, as envisaged by its advocates, a supplement to it; and the growth of ADR in England may be working in tandem with the increasing difficulty faced by many parties in accessing assistance from the courts. ${ }^{80}$ 
The alternative side to these criticisms is that Muslim ADR may indicate the possibility for creative convergence between the norms of English family law and Islamic law in handling family matters. Much discussion of the so-called "transformative accommodation" by which English law might recognise or seek to incorporate elements of Islamic law has been famously emotive, and often misconstrued as a threat to the authority of English law. ${ }^{81}$ Nevertheless, Muslim ADR, as discussed above, may be considered an existing means by which British Muslims have sought to live according to the ethical principles of the shari'ah while simultaneously working within the framework of English law. ${ }^{82}$

The elaboration of new Muslim ADR practices may be part of what some scholars have characterised as the formation of "angrezi shari "at": a set of "new, hybrid, unofficial Muslim laws" by which British Muslims have been able to operationalise "ethical-philosophical concepts" drawn from the framework of shari 'ah within the framework of the legal system. By negotiating these two legal systems, it is argued, British Muslims have managed to "build the requirements of English law into their traditional legal structures." 83 Interpreted this way, it is no wonder that mediation and arbitration - the benefits of which are acknowledged within both legal systems - have become the focus of many voices advocating a constructive accommodation between English and Islamic law.

\section{Conclusion}

Many studies have shown that the distinctive practices of Alternative Dispute Resolution at work in British Muslim communities have been deeply shaped by contemporary developments. These include the scope allowed for arbitration and mediation within contemporary English family law, as well as by attempts by British Muslims to promote community self-regulation in a new multicultural, diasporic context. ${ }^{84}$ However, this paper has sought to trace another source of these legal practices further back, in the legacies of Britain's imperial past, and in the legal norms practiced in the original homelands of first-generation immigrants. It has argued that practices of non-state arbitration and mediation took shape among Muslim communities in colonial India; and that these norms thereafter have been recreated in the British legal landscape through historical pathways of migration and cultural replication in the new environment.

As such, this paper extends John Bowen's argument that many British Muslim socioreligious institutions carry within them "remembered social forms" from South Asia. Islamic scholars who migrated to England, he notes, brought with them "background knowledge..., ideas and habits about personal status that had been developed under British rule... they assumed that Muslims could and should work out matters of marriage and divorce among themselves", and that their adjudication of shari "ah-based matters should "not depend on the state." ${ }^{85}$ I suggest in this paper that this process of transposition applies not only to the formation of institutions such as shari'ah councils, but to the recreation of culturallytransmitted mechanisms of dispute resolution that emphasise forms of intra-community mediation, arbitration and conciliation. It is a reminder of the longer-term genealogies of these legal mechanisms, that have always shown historical versatility in how they have been applied to the shifting circumstances of Muslim communities, and that are now being reproduced in response to the needs of Muslim minorities in the socio-legal landscape of modern Britain. 


\section{NOTES}

Acknowledgements: Early versions of this paper were delivered at the University of Oxford and University of Nottingham, and I am grateful for all feedback received. For useful conversations various points on the subjects discussed in this paper, I am thankful to Shaheen Sardar Ali, Amra Bone, John Bowen, Musharraf Husain, Mahmoud Jaraba, Mouez Khalfaoui, Aina Khan, Vishal Vora and Islam Uddin. Support for this research was provided by the Arts and Humanities Research Council (Ref: AH/N005856/1).

1 "Amra Bone: Transcript", in Justin Jones and Shaheen Ali, eds., "Muslim Marriage and Divorce Practices in Contemporary Britain", Islamic Law Blog, November 272019 , https://islamiclaw.blog/2019/11/27/muslim-marriage-and-divorce-practices-in-contemporarybritain-part-4-amra-bone/ [last accessed 22 December 2019]. This online symposium, referred to several times in this paper, comprises transcripts from Islamic community practitioners active in Britain. See also Amra Bone, "Islamic Marriage and Divorce in the United Kingdom: The Case for a New Paradigm" (this volume).

${ }^{2}$ The services provided by this shari 'ah council, as well as many of those described in this paper, include counselling married couples, facilitating marital reconciliation, or when necessary, expediting the most amicable, straightforward possible Islamic marital dissolutions between spouses.

${ }^{3}$ Sulh is mentioned in the Qur'an most prominently in 4:128, an ayah which exhorts married couples to seek conciliation or otherwise to seek amicable settlement. On sulh, see e.g. M. Khadduri, "Șulh", in Encyclopaedia of Islam: Second Edition (https://referenceworks.brillonline.com/browse/encyclopaedia-of-islam-2); Aida Othman, "“And Amicable Settlement is Best": Sulh and Dispute Resolution in Islamic Law', Arab Law Quarterly, Vol. 21, No. 1, 2007, pp. 64-90. For sulh as a strategy for conciliation within family law, see e.g. Sayed Sikander Shah, "Mediation in Marital Discord in Islamic Law: Legislative Foundation and Contemporary Application", Arab Law Quarterly, Vol. 23, No. 3, 2009, pp. 329-346.

${ }^{4}$ Tehkim appears in the following verses, sometimes in direct relation to family law: 4:35, 4:58, 42:40, 49:9-10. See also M. Djebeli, "Tahkīm", in Encyclopaedia of Islam: Second Edition (https://referenceworks.brillonline.com/browse/encyclopaedia-of-islam-2); for family arbitration in particular, see Mahdi Zahraa and Nora A. Hak, "Taḥīm (Arbitration) in Islamic Law Within the Context of Family Disputes", Arab Law Quarterly, Vol. 20, No. 1, 2006, pp. $2-42$.

${ }^{5}$ Mohamed Keshavjee, Islam, Sharia and Alternative Dispute Resolution: Mechanisms for Legal Redress in the Muslim Community, Delhi: I.B. Tauris, 2014, pp. 87-90.

${ }^{6}$ Othman, “"And Amicable Settlement is Best", op. cit., argues that mediation as supported by early Caliphs and jurists was a process to be prioritised over judicial proceedings, or in the absence of a functioning judiciary.

${ }^{7}$ For the argument that Islamic legal functionaries (muftis and qadis) attempt to resolve social disputes through mediation or arbitration as pre-litigation practices, hence avoiding legal 
proceedings, see Lawrence Rosen, The Justice of Islam, Oxford: Oxford University Press, 2000 .

${ }^{8}$ Respectively, Isik Tamdogan, "Sulh and the 18thC Ottoman courts of Uskudar and Adana", Islamic Law and Society, Vol. 15, No. 1, 2008, pp. 55-83; Boğaç Ergene, Local Court, Provincial Society and Justice in the Ottoman Empire, Leiden: Brill, 2002. The procedure of arbitration was also outlined in the Ottoman Mejellah-i-Akham-i-Adiliyeh, the Ottoman civil code completed in 1877 (Articles 1847-50).

${ }^{9}$ E.g. Lynn Welchman, Women and Muslim Family Laws in Arab States: A Comparative Overview of Textual Development and Advocacy, Amsterdam: Amsterdam University Press, 2007, pp. 50-53, 111-112, 121-22. In Egypt, for instance, courts are obliged by law to provide dispute resolution services, and the emphasis on mediation and reconciliation efforts increased in the wake of the legislation on divorce in 2000.

${ }^{10}$ The Muslim Family Laws Ordinance, 1961, Islamabad: Government Printing Corporation of Pakistan, 1972, Article VI.

${ }^{11}$ A key recent volume emphasising the global application of the principles of mediation and arbitration in Muslim family law, emphasising the emergence of distinctive legal cultures among minority communities around the world, is Samia Bano, ed., Gender and Justice in Family Law Dispute: Women, Mediation and Religious Arbitration, Waltham, MA: Brandeis University Press, 2017.

${ }^{12}$ David Pearl and Werner Menski, Muslim Family Law, London: Sweet \& Maxwell, 1998, pp. 77-79.

${ }^{13}$ A few particularly useful discussions of some of the major Muslim ADR forums in Britain include ibid; Keshavjee, Islam, Sharia and Alternative Dispute Resolution, op. cit.; Samia Bano, Muslim Women and Shari'ah Councils: Transcending the Boundaries of Community and Law, Basingstoke: Palgrave Macmillan, 2012, especially pp. 228-245; Ihsan Yilmaz, Muslim Laws, Politics and Society in Modern Nation State: Dynamic Legal Pluralisms in England, Turkey and Pakistan, Aldershot: Ashgate, 2005, pp. 49-82.

${ }^{14} \mathrm{https}: / /$ www.sakoon.co.uk/ [last accessed 3 January 2020]

${ }^{15} \mathrm{http}: / /$ www.barefootinstitute.com/about-us.aspx [last accessed 15 January 2020]

${ }^{16}$ https://mwrc.org.uk/ [last accessed 15 January 2020]

${ }^{17}$ These two bodies are each discussed extensively in John Bowen, On British Islam: Religion, Law, and Everyday Practice in Shari 'a Councils, Princeton: Princeton University Press, 2016; Keshavjee, Islam, Sharia and Alternative Dispute Resolution, op. cit.

${ }^{18} \mathrm{https}: / /$ theislamiccouncil.co.uk/ [last accessed 22 December 2019].

${ }^{19}$ Government Paper, The Independent Review into the Application of Sharia Law in England and Wales, February 2018, https://assets.publishing.service.gov.uk/government/uploads/system/uploads/attachment_data /file/678478/6.4152_HO_CPFG_Report_into_Sharia_Law_in_the_UK_WEB.pdf, especially pp. 11-12. 
${ }^{20}$ Ihsan Yilmaz, "Muslim Alternative Dispute Resolution and Neo-Ijtihad in England", Alternatives: Turkish Journal of International Relations, Vol. 2, No. 1, 2003, p.117.

${ }^{21}$ Yilmaz, Muslim Laws, Politics and Society, op. cit., pp. 59-63; Pearl and Menski, Muslim Family Law, op. cit.

${ }^{22}$ Keshavjee, Islam, Sharia and Alternative Dispute Resolution, op. cit., pp. 104-129.

23 The Arbitration Act of 1996 set out regulations for civil and commercial disputes to be decided out of court, while the Civil Procedure Rules ('Woolf Reforms') of 1999 sought to promote a less adversarial approach to litigation, guiding judges to recommend ADR procedures to litigants where possible.

${ }^{24}$ For further discussion of this organisation, see Bowen, On British Islam, op. cit., pp. 143172; Bano, Muslim Women and Shari'ah Councils, op. cit., pp. 241-3.

${ }^{25} \mathrm{http}: / / \mathrm{www} . \mathrm{matribunal.com/history.php} \mathrm{[last} \mathrm{accessed} 17$ December 2019].

${ }^{26}$ The organisation quotes Civil Procedure Rule 1.4 from the Ministry of Justice, which "encourag[es] the parties to use an alternative dispute resolution procedure if the court considers that to be appropriate and facilitat[es] the use of such a procedure." http://www.matribunal.com/adr-mechanisms.php [last accessed 17 December 2019].

${ }^{27}$ http://www.matribunal.com/adr.php.

${ }^{28}$ A government White Paper issued by the Lord Chancellor's Department in 1995, Looking to the Future: Mediation and the Ground for Divorce, and most significantly, the Family Justice Review Final Report (2011), both advocated a greater role for out-of-court mediations to handle family breakdowns in order to spare the parties involved from the costs, stress and rancour of formal legal proceedings. See e.g. https://www.gov.uk/government/publications/looking-tothe-future-mediation-and-the-ground-for-divorce-the-governments-proposals [last accessed 22 December 2019].

${ }^{29}$ E.g. Wendy Kennett, "It's Arbitration, But Not as We Know It: Reflections on Family Law Dispute Resolution", International Journal of Law, Policy and the Family, Vol. 30, No. 1, 2016, pp. 1-31.

${ }^{30}$ Ian Edge, "Islamic Finance, Alternative Dispute Resolution and Family Law: Developments Towards Legal Pluralism?" in Islam and English Law: Rights, Responsibilities and the Place of Shari 'a, ed. Robin Griffith-Jones, Cambridge: Cambridge University Press, 2013, pp. 121125.

31 These are, broadly speaking, the respective emphases of Keshavjee, Islam, Sharia and Alternative Dispute Resolution, op. cit.; Bano, Muslim Women and Shari'ah Councils, op. cit.; Yilmaz, Muslim Laws, Politics and Society, op. cit.

${ }^{32}$ Bano's study, for instance, explores these councils as "a new kind of faith-based approach to reconciliation and mediation within minority diasporic communities" (Muslim Women and Shari'ah Councils, op. cit., p. 3).

${ }^{33}$ Bowen, On British Islam, op. cit., pp. 54-61. On the Deobandi movement, a traditionalist Hanafi movement of Islamic renewal based around a madrasa (seminary) founded in the north 
Indian town of Deoband in 1867, see Barbara Metcalf, Islamic Revival in British India: Deoband 1860-1900, Delhi: Oxford University Press, 2002. For the Ahl-i-Hadith, a scripturalist movement that emerged in the mid-nineteenth century in Delhi, Bhopal and other cities, see ibid, pp. 268-296.

${ }^{34}$ On the "Barelwi" movement see Usha Sanyal, Devotional Islam and Politics in British India: Ahmad Riza Khan Barelwi and his Movement, 1870-1920, Delhi: Oxford University Press, 1996.

${ }^{35}$ This council is discussed in Keshavjee, Islam, Sharia and Alternative Dispute Resolution, op. cit.

${ }^{36}$ On this issue see Katharine Charsley, "Risk and Ritual: The Protection of British Pakistani Women in Transnational Marriage", Journal of Ethnic and Migration Studies, Vol. 32, No. 7, 2006, pp. 1169-1187.

${ }^{37}$ Keshavjee, Islam, Sharia and Alternative Dispute Resolution, op. cit.

${ }^{38}$ It is worth noting, too, that shari 'ah councils in Britain today include some run by Egyptian, Lebanese or Iranian scholars, and those of minority groups such as Isma'ilis.

${ }^{39}$ Bowen, On British Islam, op. cit., pp. 64, 229-30.

${ }^{40}$ Ibid, especially pp. 25-43, 52-55. For comparable discussion of a "home-away-from-home" migration and settlement pattern, see Roger Ballard, Desh Pardesh: The South Asian Experience in Britain, London: Hurst Publishers, 1994.

${ }^{41}$ This has often been identified with Warren Hastings' Plan for the Administration of Justice (1772) and various later derivations including Queen Victoria's Proclamation of 1858. Rachel Sturman, The Government of Social Life in Colonial India: Liberalism, Religious Law and Women's Rights, New York: Cambridge University Press, 2012, pp. 7-9.

42 On the colonial consolidation of Anglo-Muhammadan Law and its implications for the transformation of shari'ah, see e.g. Michael Anderson, "Islamic Law and the Colonial Encounter", in Islamic Family Law, eds. Jane Frances Connors and Chibli Mallat, London, Graham \& Trotman, 1990, pp. 205-223; Elisa Giunchi, "The Reinvention of 'Shari' a' Under the British Raj: In Search of Authenticity and Certainty", Journal of Asian Studies, Vol. 69, No. 4, 2010, pp. 1119-1142; Scott Alan Kugle, "Framed, Blamed and Renamed: The Recasting of Islamic Jurisprudence in Colonial South Asia”, Modern Asian Studies, Vol. 35, No. 2, 2001, pp. 257-313.

${ }^{43}$ For the ambivalent attitude of the 'ulama towards the colonial courts, see Muhammad Qasim Zaman, The Ulama in Contemporary Islam: Custodians of Change, Princeton: Princeton University Press, 2002, pp. 26-31.

${ }^{44}$ As argued in Metcalf, Islamic Revival in British India, op. cit., pp. 138-234.

45 'Aziz al-Rahman Usmani, Fatawe-i-Dar al-'Uloom Deoband Mudallil-va-Mukammal, Jald$i$-Awal, ("Complete and Referenced Compilation of the Fatwas of Deoband, Vol. I"), Karachi: Dar-al-Asha'at, 2002, pp. 33-36.

${ }^{46}$ E.g. Usmani, Fatawe-i-Dar al-'Uloom Deoband, op. cit. 
$\overline{47}$ Muhammad 'Ashiq Ilahi Mirathi, Tazkira't al-Rashid ("The Remembrance of Rashid Ahmad”), Lahore: Idarah-i-Islamiyyah, 1986 [first published 1908].

${ }^{48}$ Rashid Ahmad Gangohi, Fatawa-i-Rashidiyya (Kamil) ("The Complete Fatwas of Rashid Ahmad"), Delhi: Darsi Kitab-Khanah, 1987 [first published 1905], p. 194.

49 For some examples, see Ahmad Raza Khan Barelwi, Al-Fatawa al-Razaviya, Jald-iShanzdaham ("Fatwas of Ahmad Raza Khan, Vol. XVI"), Lahore: Raza Foundation, 2000, pp. 171-178. Ahmad Raza Khan is known as a prolific mufti who issued tens of thousands of fatwas. On Ahmad Raza Khan's career, see Usha Sanyal, Ahmad Riza Khan Barelwi: In the Path of the Prophet, Oxford: Oneworld, 2005.

${ }^{50}$ Barelwi, Al-Fatawa al-Razaviya.

51 Ibid., pp. 519-522.

${ }^{52}$ Muhammad Kifayat Ullah, Kifayat al-Mufti, Jald-i-Dom ("Fatwas of Kifayat Ullah, Vol. II”), Delhi: Mufti Kifayat Ullah Academy, 1993, pp. 235-241.

53 The Government of India Act XI of 1864 abolished the so-called "native law officers" (or "qadis", who had previously acted for the courts in an advisory role) and ceased the official appointment of these figures. See Uma Yaduvansh, "Decline of the Qazis (1793-1876)", The Indian Journal of Political Science, Vol. 28, No. 4, 1967, pp. 216-228.

${ }^{54}$ Mujahid al-Islam Qasmi ed., Maqalat-i-Sajjad ("Writings of Muhammad Sajjad Rahmat Ullah"), Patna: Maktabah-i-Amarat-i-Shari'ah, 1999.

${ }^{55}$ Ta 'mir-i-Fikr ("Building an Argument": Newspaper) (Bangalore), March-April 1973, p. 34; Metcalf, Islamic Revival in British India, op. cit., pp. 146-147.

${ }^{56}$ For an introduction to the Amarat-i-Shari'ah, see Ebrahim Moosa, "Shari 'at Governance in Colonial and Postcolonial India", in Islam in South Asia in Practice, ed. Barbara Metcalf, Delhi: Permanent Black, 2012, pp. 317-325.

57 This is evident through a study of the qada'iyas (judgements) made by the organisation in the 1930s-50s. Mujahid al-Islam Qasmi, ed., Qaza'iya-i-Sajjad ("The Judgements of Muhammad Sajjad Rahmat Ullah”), Patna: Amarat-i-Shari'ah, 1999.

${ }^{58}$ http://www.imaratshariah.com/darulqazaU.php [last accessed 25 January 2020].

${ }^{59}$ E.g. Qasmi, ed., Qaza'iya-i-Sajjad, op. cit., pp. 114-15, 129-32.

${ }^{60}$ Respectively, Abdul Samad Rahmani, Qaza' ke Chand Ahem Masa'il ("Some Issues in the Methods of Adjudication"), Patna: Maktaba-i-Amarat-i-Shari'ah, 1990 [first published 1959]; Abdul Samad Rahmani, Adab al-Qaza' ("Protocols of Adjudication"), Patna: Shuba-i-Asha'ati- Amarat-i-Shari'ah, 2005 [first published 1950s/60s].

61 Studies of dar-al-qaza's (shari'ah councils) in contemporary India include Katherine Lemons, "Sharia courts and Muslim personal law in India: intersecting legal regimes", Law and Society Review, Vol. 52, No. 3, 2018, pp. 603-629; Jeffrey Redding, "The case of Ayesha, Muslim 'courts' and the rule of law: some ethnographic lessons for legal theory", Modern Asian Studies, Vol. 48, No. 4, 2014, pp. 940-85. 
${ }^{62}$ E.g. Julia Stephens, Governing Islam: Law, Empire and Secularism in South Asia, New York: Cambridge University Press, 2018; Wael Hallaq, Shari'a: Theory, Practice, Transformations, New York: Cambridge, 2009, pp. 371-395.

${ }^{63}$ The tradition in question, transmitted in the Musannaf of the eighth century al-San 'ani, reads: "Dispel the disputants until they settle amicably with one another: for truly adjudication leads to rancour." For elaboration, see Othman, "And Amicable Settlement is Best", op. cit., pp. 69, 73-76. This article also recounts a series of equivalent statements by other Caliphs and later jurists.

64 'Abd al-Islam Nadvi, Al-Qada'fi al-Islam, Lucknow: Dar-al-Matbah Mu'arif-i-Tabah, 1929, pp. 7-8.

${ }^{65}$ Rahmani, Adab al-Qaza', op. cit., pp. 49-52.

${ }^{66}$ E.g. Qasmi, ed., Qaza 'iya-i-Sajjad, op. cit., p. 131.

67 'Abd al-Samad Rahmani, Kitab al-Faskh va al-Tafriq (“A Book of Marital Dissolution”), Patna: Maktaba-i-Amarat-i-Shari'ah, 2001-2 [first published 1967-68], pp. 153-157. This event is attributed to the Companion 'Ubaidah as-Salmani and appears in major works of fiqh, such as the Kitab al-Umm. Rahmani himself turns to the commentaries of early modern Qur'anic exegetes, especially the Tafsir-i-Mazhari of Thana Ullah Panipati (d.1810), to elaborate this ayah's meanings.

${ }^{68}$ Ibid.

69 As argued in Gopika Solanki, Adjudication in Religious Family Laws: Cultural Accommodation, Legal Pluralism and Gender Equality, New York: Cambridge University Press, 2011. For further discussion of India's pluralist legal landscape of family law, see especially Flavia Agnes and Shoba Venkatesh Ghosh, eds., Negotiating Spaces: Legal Domains, Gender Concerns and Community Constructs, Delhi: Oxford University Press, 2012.

${ }^{70}$ As described in e.g. Sylvia Vatuk, Marriage and its Discontents: Women, Islam and the Law in India, Delhi: Kali for Women, 2017; Katherine Lemons, Divorcing Traditions: Islamic Law and the Making of Secularism, Ithaca and London: Cornell University Press, 2019. See also studies of dar-al-qada's (shari'ah councils) in contemporary India including Katherine Lemons, "Sharia Courts and Muslim Personal Law in India", op. cit., pp. 603-629; Jeffrey Redding, "The Case of Ayesha, Muslim 'Courts' and the Rule of Law", op. cit., pp. 940-85.

${ }^{71}$ E.g. Muhammad Azam Chaudhary, Justice in Practice: Legal Ethnography of a Pakistani Punjabi Village, Karachi: Oxford University Press, 1999.

${ }^{72}$ E.g. for discussion of the "parallel judicial system" of shari 'ah courts established by Jama'atud-Da'wa, a religious organisation, in Punjab province, see The Times of India (world edition), 20 April 2016.

${ }^{73}$ Mohammad Tarikul Islam, "Rural Dispute Resolution in Bangladesh: How Do Village Courts Safeguard Justice?", Contemporary South Asia, Vol. 27, No. 1, 2019, pp. 58-65.

${ }^{74}$ For summative reflection on the interactions between the treatment of "religion" in colonial India and imperial Britain, see Peter Van Der Veer, Imperial Encounters: Religion and Modernity in India and Britain, Princeton: Princeton University Press, 2001, esp. pp. 14-29. 
75 "Musharraf Husain: Transcript", in Jones and Ali, eds., "Muslim Marriage and Divorce", op. cit., $\quad$ https://islamiclaw.blog/2019/11/26/muslim-marriage-and-divorce-practices-incontemporary-britain-part-3-musharraf-husain/ [last accessed 19 January 2020]. Husain is a high-profile imam and community leader based in Nottingham.

${ }^{76}$ For a useful summary of these arguments, see Caryn Litte Wolfe, "Faith-Based Arbitration: Friend or Foe? An Evaluation of Religious Arbitration Systems and their Interaction with Secular Courts', Fordham Law Review, Vol. 75, No. 1, 2006, pp. 430-432, 440-442, 451-459.

${ }^{77}$ Ibid, pp. 459-466.

78 "Aina Khan: Transcript", in Jones and Ali, eds., "Muslim Marriage and Divorce", op. cit., https://islamiclaw.blog/2019/11/22/muslim-marriage-and-divorce-practices-in-contemporarybritain-part-2-aina-khan/ [last accessed 24 January 2020].

79 Lucy Carroll, "Muslim Women and 'Islamic Divorce' in England”, Journal of Muslim Minority Affairs, Vol. 17, No. 1, 1997, pp. 97-115.

${ }^{80}$ This is especially the case in the aftermath of the Family Justice Review (2011), which promoted greater reliance on out-of-court mediation in family affairs, and the Legal Aid, Sentencing and Punishment of Offenders Act (2012), which cut legal aid funding from family litigation and so deprived victims of access to court proceedings. "Aina Khan: Transcript", op. cit.

${ }^{81}$ This was famously the case with Revd. Rowan Williams' speech on this issue in 2008. See Robin Griffith-Jones, ed., "The 'Unavoidable" Adoption of Shari 'a Law - the Generation of a Media Storm" in Islam and English Law, ed. R. Griffith-Jones, pp. 20-33.

${ }^{82}$ Keshavjee, Islam, Sharia and Alternative Dispute Resolution, op. cit.; Edge, "Islamic Finance, Alternative Dispute Resolution and Family Law", op. cit.

${ }^{83}$ Pearl and Menski, Muslim Family Law, op. cit., pp. 58-9, 74-77.

${ }^{84}$ As noted above, examples include Pearl and Menski, Muslim Family Law, op. cit.;

Keshavjee, Islam, Sharia and Alternative Dispute Resolution, op . cit.; Samia Bano, Muslim Women and Shari'ah Councils, op. cit.; Ihsan Yilmaz, Muslim Laws, Politics and Society, op. cit.

${ }^{85}$ Bowen, On British Islam, op. cit., p. 54. 